\title{
Removal of Ni (II) and Cu (II) from their Solutions and Waste Water by Nonliving Biomass of Pseudomonas oleovorans
}

\section{Neha Singh* and Ranu Gadi}

School of Applied Sciences, Indira Gandhi Institute of Technology (IGIT), GGSIP University, Delhi, India

\begin{abstract}
The nonliving biomass of Pseudomonas oleovorans was used for the removal of Nickel and Copper from their single and binary solutions. The optimum conditions such as $\mathrm{pH}$, initial metal ion concentration, contact time and biomass dose were determined experimentally. $\mathrm{q}_{\mathrm{max}}$ and 'b' values for $\mathrm{Ni}(\mathrm{II})$ were $95.6 \mathrm{mg} / \mathrm{g}$ and 0.010 and for $\mathrm{Cu}(\mathrm{II}) 137.5 \mathrm{mg} / \mathrm{g}$ and 0.008 respectively. The removal of the metals was studied in binary metal systems also. The developed method was applied for the removal of the metals from the wastewater samples. The investigations on the speciation of the metals revealed that both $\mathrm{Ni}$ and $\mathrm{Cu}$ exist as hydrated $\mathrm{Ni}$ (II) and $\mathrm{Cu}$ (II) ions and precipitates of $\mathrm{Ni}(\mathrm{OH})_{2}$ and $\mathrm{Cu}(\mathrm{OH})_{2}$ at different $\mathrm{pH}$ ranges.
\end{abstract}

Keywords: Pretreatment; pH; Time; Langmuir isotherm; Binary; Stability.

\section{Introduction}

The removal of toxic metal contaminants from wastewater is one of the most important environmental concerns being faced by many countries these days. Although this issue has been addressed for many years, effective treatment options are limited. Chemical precipitation, ion exchange, reverse osmosis, and solvent extraction are the most commonly used procedures for removing metal ions from dilute solutions [1]. However these methods are not appreciably successful at low metal concentrations often encountered in wastewater. Biosorption, the process of passive cation binding by dead or living biomass, represents a potentially cost-effective way of eliminating toxic heavy metals from industrial wastewater. The abilities of bacterial masses to remove metal ions in solutions have been studied by different workers [2-4] because of their high surface to volume ratio and high content of potentially active chemisorption sites. As single toxic metallic species rarely exists in natural and waste waters, any approach that attempts to remove heavy metals from multi-component systems using bacteria will be of great use. The present study was undertaken to probe the potential of nonliving biomass of Pseudomonas oleovorans (P.oleovorans) to remove nickel and copper by biosorption process from single metal ion and binary metal ion systems and from the waste water. P.oleovorans is a gram-negative bacterial species whose cell wall contains peptidoglycan, lipopolysaccharide and protein [5] which make available donor atoms to form bonds with metals. It was also aimed to investigations on the speciation of the metals in the solution at different $\mathrm{pH}$ ranges were made on the basis of biosorption process.

\section{Materials and Methods}

\section{Growth of bacterial biomass}

Culture of Pseudomonas oleovorans (MTCC-617) was procured from microbial type culture collection and gene bank, Institute of Microbial Technology (CSIR) Chandigarh, India. Revival of culture was done by growing the species on prescribed growth medium (Composition-nutrient agar). The medium was prepared, autoclaved and allowed to cool. Loop full of the bacterial culture was taken and streaked on the petriplates containing prescribed medium in laminar air flow chamber. The inoculated plates of P.oleovorans were incubated at $25^{\circ} \mathrm{C}$ for 24 hours. Biomass of the species was separated from the medium by centrifugation and was dried in hot air oven at $60^{\circ} \mathrm{C}$.

\section{Pretreatment of nonliving biomass of P.oleovorans}

$10 \mathrm{~g}$ of the harvested biomass of the bacterial species was treated with $100 \mathrm{~mL}$ of $0.1 \mathrm{~N} \mathrm{NaOH}$ for 1 hour. The pretreated biomass was centrifuged and the residue of the biomass was taken in a $100 \mathrm{~mL}$ beaker and was washed for 3-4 times with double distilled water and again centrifuged. The centrifuged biomass was dried at $60^{\circ} \mathrm{C}$ for 24 hours in hot air oven.

\section{Solutions}

The aqueous solutions of metal ions were prepared by using AnalR grade chemicals in double distilled water. Stock solutions of nickel and copper ions each of $1000 \mathrm{ppm}$ concentration were prepared by taking nickel chloride and copper sulphate respectively. From these stock solutions, the solutions of desired concentrations were prepared by diluting with double distilled water. Desired $\mathrm{pH}$ values (measured by systronics digital $\mathrm{pH}$ meter) of different systems were adjusted by adding $0.1 \mathrm{~N} \mathrm{NaOH}$ and $0.1 \mathrm{~N} \mathrm{HCl}$. Binary metal ion solutions of nickel and copper were prepared by taking metal ion concentrations in 1:1 ratio. Study on the speciation of metals was made by changing the $\mathrm{pH}$ of the metal ion solutions in contact with the biomass during biosorption experiments. The waste water samples were collected from two sites; from Tawa River at a distance of three kilometers from coal mines, Pathakhara, Sarni, District Betul discharging effluents in the river and from the outlet of upper Lake of Bhopal, India.

\section{Apparatus}

Metal ion concentrations were determined using Perkin-Elmer

*Corresponding author: Neha Singh, School of Applied Sciences, Indira Gandhi Institute of Technology (IGIT), GGSIP University, Delhi, India, E-mail: nehasindhu@gmail.com

Received December 29, 2011; Accepted January 20, 2012; Published January 23, 2012

Citation: Singh N, Gadi R (2012) Removal of Ni (II) and Cu (II) from their Solutions and Waste Water by Nonliving Biomass of Pseudomonas oleovorans. Hydrol Current Res 3:126. doi:10.4172/2157-7587.1000126

Copyright: (ㅇ 2012 Singh N, et al. This is an open-access article distributed under the terms of the Creative Commons Attribution License, which permits unrestricted use, distribution, and reproduction in any medium, provided the original author and source are credited. 
Instruments, Shelton, USA, Model A analyst 100 with air - acetylene flame (AAS). The wave lengths used for nickel and copper were 232.0 $\mathrm{nm}$ and $324.8 \mathrm{~nm}$ respectively.

\section{Biosorption experiments}

To study the effect of $\mathrm{pH}$ (2.0-10.0), biomass dose (40-240 mg in $100 \mathrm{~mL}$ solution), contact time (20-120 min) and initial metal ion concentration $(25-200 \mathrm{mg} / \mathrm{L})$, the biosorption experiments were conducted in $250 \mathrm{~mL}$ Erlenmeyer flasks containing $100 \mathrm{~mL}$ solution of the metal ion of varying concentrations and different amounts of nonliving biomass of P.oleovorans. In each experiment, one of the conditions was changed while other conditions were kept constant. The flasks were agitated on an incubator shaker (Innova 4230, New Brunswick Scientific, USA) at a constant speed of $150 \mathrm{rpm}$ for different time periods. The temperature during experiments was $30^{\circ} \mathrm{C}$. It is to be added here that in case of temperature contrasting results have been obtained regarding its effect on biosorption by different biomasses. However, the temperature does not seem to influence the biosorption process in the range of $20^{\circ} \mathrm{C}-35^{\circ} \mathrm{C}$ [6]. Also, biosorption process is usually not operated at high temperatures because it will increase the operational cost [7].

After each interaction of metal ion with the biomass at a predetermined time period, the matrix was centrifuged and the amount of metal in the supernatant was determined by AAS technique. Before measurement, the supernatants of each metal were appropriately diluted with double distilled water to ensure that the metal concentration in the sample was linearly dependent on the absorbance. Biosorption experiments were conducted in duplicate and average values were used in the analysis. The biosorbent amount was calculated as follows:

$$
\mathrm{q}=\mathrm{V}\left(\mathrm{C}_{\mathrm{i}}-\mathrm{C}_{\mathrm{f}}\right) / \mathrm{m}
$$

Where $\mathrm{q}$ is the metal uptake ( $\mathrm{mg}$ metal per gram biosorbent), $\mathrm{V}$ the liquid sample volume $(\mathrm{mL}), \mathrm{C}_{i}$ the initial concentration of the metal in the solution $(\mathrm{mg} / \mathrm{L}), \mathrm{C}_{\mathrm{f}}$ the final (equilibrium) concentration of the metal in the solution $(\mathrm{mg} / \mathrm{L})$ and $\mathrm{m}$ is the amount of the added dried biosorbent (mg).

The equilibrium of the biosorption process is often described by fitting the experiment points with models such as Langmuir and Freundlich isotherm models [2]. In the present study only Langmuir model [8] which works for monolayer adsorption has been used.

The Langmuir equation can be given as

$$
\mathrm{q}=\frac{\mathrm{bC}_{f} \mathrm{q}_{\max }}{1+\mathrm{bC}_{f}}
$$

On rearranging the above equation, we get

$$
\frac{1}{q}=\frac{1}{b \cdot q_{\max }} \cdot \frac{1}{C_{f}}+\frac{1}{q_{\max }}
$$

Where $\mathrm{q}$ is the amount of metal sorbed $(\mathrm{mg} / \mathrm{g}), \mathrm{C}_{\mathrm{f}}$ is the final (equilibrium) concentration of the metal in solution $\left(\mathrm{mg} / \mathrm{L}\right.$ ) and $\mathrm{q}_{\max }$ is the maximum amount of metal ion which can be taken up by the biosorbent $(\mathrm{mg} / \mathrm{g})$, ' $b$ ' is the Langmuir constant. The linear Langmuir plot was obtained by plotting $1 / \mathrm{q}$ vs $1 / \mathrm{C}_{\mathrm{f}}$ on $\mathrm{y}$ and $\mathrm{x}$-axis respectively. The values of $\mathrm{q}_{\max }$ and ' $\mathrm{b}$ ' were calculated from the y-axis intercept and slope of the linear plot respectively. The value obtained for the $\mathrm{q}_{\max }$ signifies the maximum absorption capacity $(\mathrm{mg} / \mathrm{g})$ and ' $\mathrm{b}$ ' is a constant related to the affinity between the metal and the biomass.

\section{Biosorption experiments on the binary system of nickel and copper}

To study the binary system of copper and nickel, $100 \mathrm{~mL}$ mixture solution of the metal (concentration of each metal ion $100 \mathrm{mg} / \mathrm{L}$ ) were treated with nonliving biomass of P.oleovorans at optimum conditions in respect of $\mathrm{pH}$, contact time, biomass dose. Other steps followed were same as for single metal systems.

\section{Application of the developed method for the determination of metals in wastewater samples}

Samples of wastewater from two sites were collected in plastic container from $15 \mathrm{~cm}$ depth below the surface of wastewater in triplicate and mixed to get composite sample. The samples were preserved in refrigerator by adding $1.5 \mathrm{~mL}$ of concentrated $\mathrm{HNO}_{3}$ to $1 \mathrm{~L}$ of waste water samples. The samples were digested with $\mathrm{HNO}_{3}$ as per procedure recommended by APHA, AWWA, WFCF [9]. The digested water was filtered and the concentration of metal ion was determined by AAS. After that the developed method was applied to wastewater samples following optimum conditions and the analyses of results were made.

\section{Metal speciation studies}

The biosorption of the metals by the biomass depends on their chemical speciation which, in turn, depends on the change in $\mathrm{pH}$ range of the solutions. Thus, biosorption capacity can be used for determining the speciation of metals. The biosorption experiments carried out to investigate the effect of $\mathrm{pH}$ on biosorption capacity were used for studying the speciation of the metals in solutions.

\section{Results and Discussion}

\section{Effect of $\mathbf{p H}$}

The $\mathrm{pH}$ of the solution has a very significant effect on metal ion solubility and surface charge of the biomass [10] which, in turn, influences the biosorption process. The nature of the curves (Figure 1) of $\mathrm{Ni}$ (II) and $\mathrm{Cu}$ (II) biosorption by P.oleovorans shows that in case of $\mathrm{Ni}(\mathrm{II})$, pH rises sharply from 2.0 to 5.0 and then becomes nearly constant from 5.0 to 7.0 After that, there is only slight increase in the biosorption. In case of $\mathrm{Cu}$ (II), the biosorption increases sharply from $\mathrm{pH} 2.0$ to 4.0 , then becomes nearly constant from $\mathrm{pH} 4.0$ to 6.0 and after that there is only slight increase from $\mathrm{pH} 6.0$ to 10.0 . The less amount of biosorption at lower $\mathrm{pH}$ values is due to the fact that the cell wall of the bacterial biomass is closely associated with $\mathrm{H}_{3} \mathrm{O}^{+}$and access of metal ions to cell wall would be obstructed as a result of repulsion. The metal uptake increases from $\mathrm{pH}$ 2.0-5.0 in case of $\mathrm{Ni}(\mathrm{II})$ and 2.04.0 in case of $\mathrm{Cu}(\mathrm{II})$. This is due to the fact that the more ligands with negative charge are exposed with the subsequent increase in attraction sites to positively charged metal ions [11]. After some $\mathrm{pH}$ range the sorption becomes higher due to the precipitation of hydroxide of metals which depend on the solubility products of their hydroxides (solubility products of $\mathrm{Ni}(\mathrm{OH})_{2}$ and $\mathrm{Cu}(\mathrm{OH})_{2}$ are $2 \times 10^{-15}$ and $5 \times$ $10^{-20}$ respectively) [12]. Therefore, at the same concentration of each metal ion the $\mathrm{pH}$ required for precipitation will fall in the order $\mathrm{Ni}>$ $\mathrm{Cu}$ which is in consonance with the results. It can be concluded that the percentage removal of $\mathrm{Ni}$ (II) and $\mathrm{Cu}$ (II) at high $\mathrm{pH}$ values is mainly due to simultaneous biosorption and precipitation [13]. 
Citation: Singh N, Gadi R (2012) Removal of Ni (II) and Cu (II) from their Solutions and Waste Water by Nonliving Biomass of Pseudomonas oleovorans. Hydrol Current Res 3:126. doi:10.4172/2157-7587.1000126

\section{Effect of biomass dose}

Biomass dose of the species when varied from $40 \mathrm{mg}-240 \mathrm{mg}$ in $100 \mathrm{~mL}$ metal ion solution of $100 \mathrm{mg} / \mathrm{L}$ concentration, it was found that there was an increase in biosorption with the increase of biomass but at higher biomass dose the increase was marginal (Figure 2). The increase in percentage removal is due to the increase in surface area of the biomass and the availability of the adsorption sites [14]. The reason for the constancy of the removal after some point lies in the fact that the screen effect takes place amongst the dead cells which block the active sites of the cells by an increase of biomass [15]. On the basis of the above study, $0.1 \mathrm{~g}$ of biomass in $100 \mathrm{~mL}$ solution of metal ions was chosen for further studies.

\section{Effect of contact time}

The effect of contact time on the biosorption of $\mathrm{Ni}$ (II) and $\mathrm{Cu}$ (II) is shown in Figure 3. It is observed that the biosorption increased with the time in the beginning but after 80 minutes contact time it remained constant for both the metal ions. It is known that the role of metal uptake is influenced by the factors affecting mass transfer from the bulk solution to binding sites [16]. In the present case, the experimental conditions allowed normal mixing of the metal ions and the biomass in the system which partially suppressed some kinetic factors leading to attainment of the equilibrium at a short time $(80 \mathrm{~min})$. However, to ensure the complete constancy of time 90 minutes time period was used for further studies.

\section{Effect of initial metal Ion concentration}

When $0.1 \mathrm{~g}$ of biomass of P.oleovorans was treated with $100 \mathrm{~mL}$ solution of both the metals in different concentrations (25 mg -200 $\mathrm{mg} / \mathrm{L}$ ), percentage removal of each metal regularly decreased with the increase in metal concentration (Table 1). This is due to the fact that at lower concentration the metal ions are fully absorbed at the active sites and later only a few sites are available for absorption. For further studies $100 \mathrm{mg} / \mathrm{L}$ solution of both the metal ions was used with the intent of showing the usefulness of the metal for removal of metal ions from dilute solutions where classical methods fail.

For the quantification of the capacity of the biomass of P.oleovorans to remove the title metals from the aqueous solutions, the data of change in the amount of biosorption with initial concentration were used for calculating $\mathrm{q}$ (specific metal uptake in $\mathrm{mg} / \mathrm{g}$ ) values. The Langmuir [8] isotherms were drawn by plotting $1 / \mathrm{q}$ vs $1 / \mathrm{C}_{\mathrm{f}}$ It was found that the

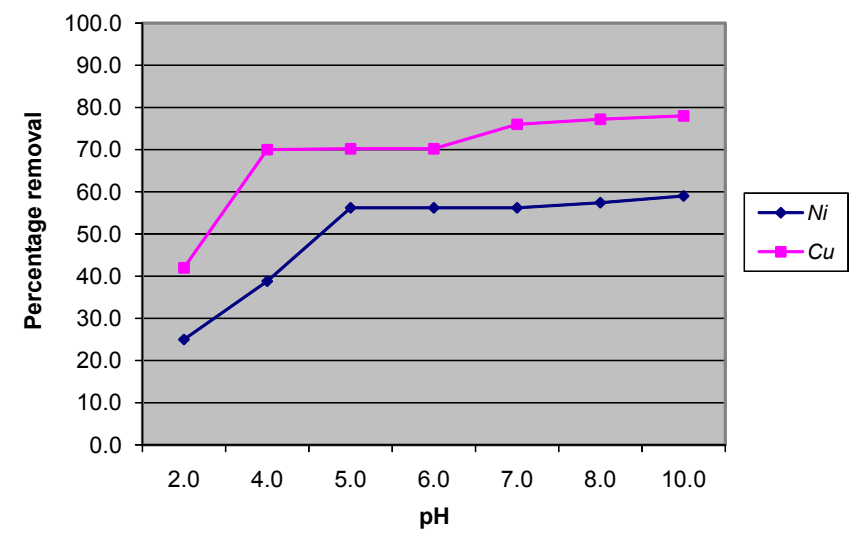

Figure 1: Effect of $\mathrm{pH}$ on biosorption of $\mathrm{Ni}(\mathrm{II})$ and $\mathrm{Cu}(\mathrm{II})$ by $P$. oleovorans.

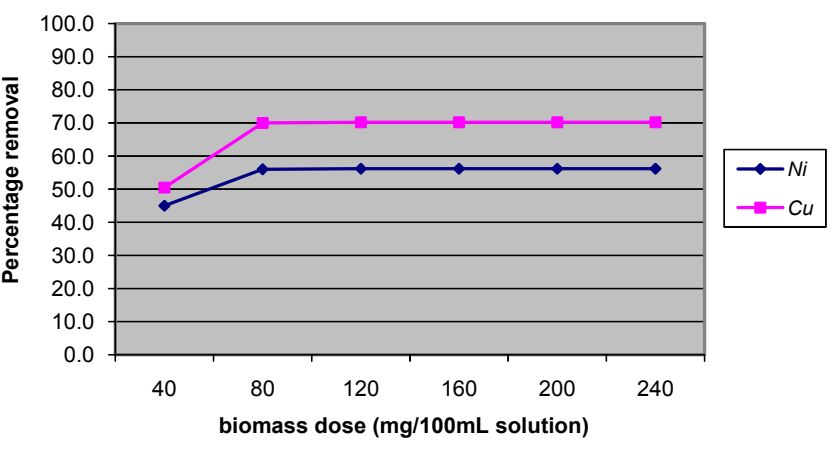

Figure 2: Effect of biomass dose on biosorption of $\mathrm{Ni}(\mathrm{II})$ and $\mathrm{Cu}(\mathrm{II})$ by P.oleovorans

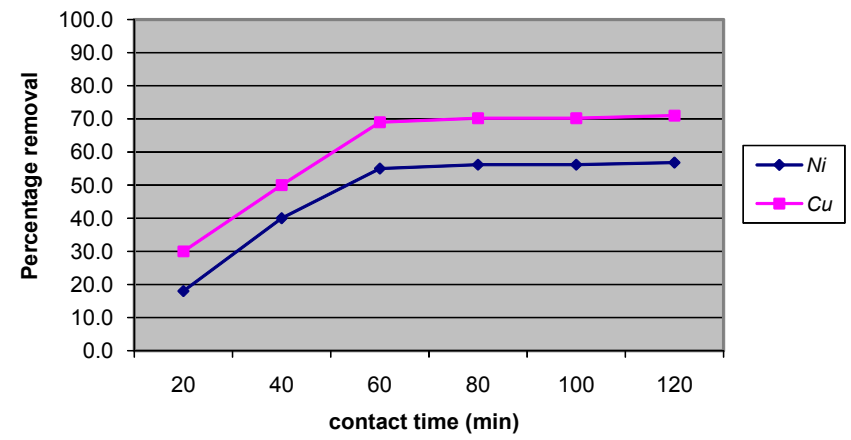

Figure 3: Effect of contact time on biosorption of $\mathrm{Ni}(\mathrm{II})$ and $\mathrm{Cu}(\mathrm{II})$ by P.oleovorans

\begin{tabular}{|c|c|c|c|}
\hline \multicolumn{2}{|c|}{$\mathrm{Ni}(\mathrm{II})$} & \multicolumn{2}{c|}{$\mathrm{Cu}(\mathrm{II})$} \\
\hline $\begin{array}{c}\text { Initial concentration } \\
(\mathrm{ppm})\end{array}$ & $\begin{array}{c}\text { Percent } \\
\text { removal }\end{array}$ & $\begin{array}{c}\text { Initial concentration } \\
\text { ppm }\end{array}$ & Percent removal \\
\hline 25 & 84.0 & 25 & 90.0 \\
\hline 50 & 72.0 & 50 & 85.4 \\
\hline 75 & 66.8 & 75 & 78.0 \\
\hline 100 & 56.2 & 100 & 70.2 \\
\hline 125 & 51.2 & 125 & 66.0 \\
\hline 150 & 48.3 & 150 & 61.0 \\
\hline 175 & 44.0 & 175 & 58.1 \\
\hline 200 & 42.0 & 200 & 51.0 \\
\hline
\end{tabular}

$\mathrm{pH} 6.0$, temp $60^{\circ} \mathrm{C}$, Contact time 90 minutes, biomass dose $0.1 \mathrm{~g}$ in $100 \mathrm{~mL}$ metal ion solution

Table 1: Effect of Initial concentrations of $\mathrm{Ni}$ (II) and $\mathrm{Cu}$ (II) on their Biosorption by P.oleovorans.

graphs were linear at low concentration range but deviated at high concentration it may be attributed to the use of Lineweaver-Burk [17] equation which is strongly biased towards fitting data in the low concentration range or to sites (such as $-\mathrm{COO}^{-}, \mathrm{OH}^{-},-\mathrm{NH}_{2}$ ) at surface not having equal affinity for adsorbate which is requirement for validity of Langmuir model [8]. $\mathrm{q}_{\max }$ and ' $\mathrm{b}$ ' values were calculated from the data related low concentration range $\left(\mathrm{q}_{\max }\right.$ and ' $\mathrm{b}$ ' values for $\mathrm{Ni}$ are 95.6 $\mathrm{mg} / \mathrm{g}$ and 0.010 and for $\mathrm{Cu} 137.5 \mathrm{mg} / \mathrm{g}$ and 0.008 respectively). The $\mathrm{q}_{\max }$ value in case of $\mathrm{Cu}$ (II) is more than $\mathrm{Ni}$ (II) which shows that $\mathrm{Cu}$ (II) has more affinity for the biomass than $\mathrm{Ni}$ (II). This is in consonance with the Irving - Williams series [18] developed for the stability constants for the formation of complexes. The ' $b$ ' value for $\mathrm{Cu}$ (II) is lesser than 
Citation: Singh N, Gadi R (2012) Removal of Ni (II) and Cu (II) from their Solutions and Waste Water by Nonliving Biomass of Pseudomonas oleovorans. Hydrol Current Res 3:126. doi:10.4172/2157-7587.1000126

that of Ni. This is expected as lesser value of ' $b$ ' shows more affinity of the metal for biomass resulting high $\mathrm{q}_{\max }$ value of $\mathrm{Cu}$ (II) [19].

\section{Biosorption of binary mixture of $(\mathrm{Ni}+\mathrm{Cu})$ by nonliving biomass of P.oleovorans}

The industrial effluents generally include more than one metal. The presence of multi metals in the solutions affects the removal of a particular metal by absorption due to competitive interactions with the biomass of bacterial species. When binary solutions of $\mathrm{Ni}$ (II) and $\mathrm{Cu}$ (II) taken in $1: 1$ ratio (optimum concentration of each metal, 100 $\mathrm{mg} / \mathrm{L}$ ) were treated with $0.1 \mathrm{~g}$ of biomass of P.oleovorans under same optimum conditions as used in single metal systems, the percentage removal was $38.2 \%$ for $\mathrm{Ni}$ (II) and $54.8 \%$ for $\mathrm{Cu}$ (II) which in both the cases is lesser than the single metal ion systems [56.2 \% for $\mathrm{Ni}$ (II) and $70.2 \%$ for $\mathrm{Cu}(\mathrm{II})]$.

This decrease in percentage removal is due to increased competition between the same charged metals $(+2)$ for binding sites of the biomass.

\section{Application of the developed method for the removal of metals from wastewater}

The proposed method was applied for the removal of $\mathrm{Ni}(\mathrm{II})$ and $\mathrm{Cu}$ (II) metals present in the wastewater samples collected from the Tawa River, Sarni, District Betul, and outlet of Upper Lake, Bhopal (India). The concentration of $\mathrm{Ni}$ and $\mathrm{Cu}$ in the sample determined following the procedure developed by APHA, AWWA, WPCF [9] were Ni 8.4ppm and $\mathrm{Cu} 4.64 \mathrm{ppm}$ in Tawa river and Ni, NIL, Cu $1.6 \mathrm{ppm}$ on the outlet of Upper Lake. The method could remove $62.0 \% \mathrm{Ni}$ and $65.0 \% \mathrm{Cu}$ from Tawa River and $63.6 \% \mathrm{Cu}$ from the outlet of Upper Lake (nickel being NIL in the upper lake)

\section{Speciation aanalysis of $\mathrm{Ni}$ (II) and $\mathrm{Cu}$ (II) by the biosorption onto the biomass of P.oleovorans}

The data of percent removal with the $\mathrm{pH}$ change were exploited for the speciation analysis of $\mathrm{Ni}$ and $\mathrm{Cu}$ metals in solution. From the Figure 1 it is clear that there is sharp increase in biosorption from $\mathrm{pH} 2.0$ to 5.0 in case of $\mathrm{Ni}$ and from 2.0 to 4.0 in case of copper. After that $\mathrm{pH}$ range remains constant 5.0 to 7.0 for $\mathrm{Ni}$ and 4.0 to 6.0 for $\mathrm{Cu}$. After that in both the cases again there is increase which is due to biosorption and precipitation of both the metals. From these data it can be concluded that in the beginning only hydrated metal ions are present and at higher $\mathrm{pH}$ values (7.0 for $\mathrm{Ni}$ and 6.0 for $\mathrm{Cu}$ ), the hydroxide formation starts which increases the sorption. Therefore above $\mathrm{pH} 7.0$ in case of $\mathrm{Ni}$ and 6.0 in case of $\mathrm{Cu}$, hydroxides are also present.

\section{Conclusion}

The present study clearly indicates that at nearly normal optimum conditions, the nonliving biomass of Pseudomonas oleovorans can be used for the removal of $\mathrm{Ni}$ and $\mathrm{Cu}$ from their aqueous solution and waste water samples. The method can work satisfactorily for dilute solutions also. The optimum $\mathrm{pH}$, biomass dose, contact time and initial metal ion concentration are 6.0, $0.1 \mathrm{~g}$ in $100 \mathrm{~mL}, 90 \mathrm{~min}, 100 \mathrm{mg} / \mathrm{L}$ respectively. Nickel and copper are found as their hydrated ions and hydroxides at different $\mathrm{pH}$ ranges.

\section{References}

1. Rich G, Cherry K (1987) Hazardous waste Treatment Technologies. Pudvan Pub Co 169.

2. Gadd GM, white C, De Rome L (1988) Heavy metal and rachonuclide uptake by fungi and yeast. $\mathrm{Zn}$ : Biohydrometallurgy, edited by P.R. Norris and D.P. Kelly (a. Rowe Chippenham, Wilts, U.K.)
3. Chatterjee SK, Chandra G, Bhattacharjee I (2010) Biosorption of heavy metals from industrial waste water by Geobacellus thermodenitrificans. J Hazard Mater 175: 117-125

4. Kang SY, Lee JU, Kim KW (2005) Metal Removal from wastewater by bacteria sorption: kinetics and competition studies. Environ Technol 26: 615-624.

5. Salton MJR, Kim KS (1996) Structure in: Baron's Medical Microbiology (Baron et al, eds) ( $4^{\text {th }}$ ed.) University of Texas Medical Research, ISBN No. -9631512 $1-1$.

6. Aksu Z, Yesim S, Tulin K (1992) The biosorpnon of Copperod by C. vulgaris and $Z$. ramigera. Environ Technol 13: 579-586.

7. Wang J (2002) Biosorption of Copper (II) by chemically modified biomass of Saccharomyes cerevisiae. Process Biochem 37: 847-850.

8. Langmuir I (1918) The adsorption of gases on plane surfaces of glass, mica and platinum. J Am Chem Soc 40: 1361-1403.

9. APHA, AWWA, WPCF (1995) Standard methods for the determination of water and wastewater. Am Public Health Assoc, Washington DC.

10. Guibal E, Saucedo I, Roussy J, Le CP (1994) Uptake of Uranyl ionsby new sorbing polymers : discussion of adsorption isotherms and $\mathrm{pH}$ effect. React Polym 23: 147-156.

11. Setatnia A, Madami MZ, Bakhti LY, Mansouri, Yous R (2004) Biosorption of $\mathrm{Ni}^{2+}$ from aqueous solution by a $\mathrm{NaOH}$ treated bacterial dead Streptomices rimosus biomass. Mineral Eng 17: 903-911.

12. Agasyan PK, Tsyurupa MC (1976) Qualitative Chemical Semi microanalysis Mir Publishers, Moscow, p 170.

13. Al-quodah Z (2006) Biosorpption of heavy metal ions from aqueous solutions by activated sludge. Desalination 196: 164-176.

14. Burno BYM, Torem MC, Molina F, de Mesquito LMS (2008) Biosorption of lead (II), Chromium (II) and Copper (II) by R. obacus: Equilibrium and Kinetic studies. Mineral Eng 21: 65-75.

15. Hammaini A, Gonzalez F, Ballester A, Blazquez ML, Munoz JA (2007) Biosorption of a heavy metals by activated sludge and their desorption characteristics. J Environ Manage 84: 419-426.

16. Weber WJ Jr (1985) Adsorption theory, concepts and models, In : Schijko, F.L. (ed.). Adsorption Technology: A Step-by-step Approach to process Evaluation and Application, Marcel Dekkar, NY, 1-35

17. Lineweaver H, Burk D (1934) Determination of enzyme dissociation constants. J Am Chem Soc 56: 658-666.

18. Irving H, Williams RJP (1953) The stability of transition-metal complexes. J Chem Soc 3192-3210.

19. Jalali R, Bhajourian H, Asif Y, Davarpanash SJ, Sepher S (2002) Removal and recovery of lead using non-living biomass of algae. J Hazard Mater 92 253-262.

20. Gadd GM (1990) Heavy metal accumulation by bacteria and other microorganisms. Cellular and Molecular Life Sciences 46: 834-840.

21. Davis TA, Volesky B, Mucci A (2003) A review of the biochemistry of heavy metal biosorption by brown algae. Water Res 37: 4311-4330. 